\title{
Prolactin-releasing peptide in the ewe: cDNA cloning, mRNA distribution and effects on prolactin secretion in vitro and in vivo
}

\author{
J D Curlewis, D H L Kusters, J L Barclay and S T Anderson
}

School of Biomedical Sciences, Department of Physiology and Pharmacology, The University of Queensland, Queensland 4072, Australia

(Requests for offprints should be addressed to J D Curlewis; Email: j.curlewis@mailbox.uq.edu.au)

\begin{abstract}
RT-PCR followed by $5^{\prime}$ - and 3 '- rapid amplification of cDNA ends was used to clone and sequence ovine prolactin-releasing peptide (PrRP). The cDNA was characterised by short $5^{\prime}$ - and $3^{\prime}$-untranslated regions and a GC-rich (71\%) coding region. The nucleotide and deduced amino acid sequences for the coding region showed 95.6 and $94.9 \%$ identity with bovine PrRP but the amino acid sequence of PrRP31 was conserved between these species. Northern blot analysis and RT-PCR showed that, as in the rat, the peptide was more abundantly expressed in the brainstem than the hypothalamus. However, in the ovine hypothalamus, PrRP mRNA expression was more widespread than in the rat, with expression detected in both rostral and caudal parts of the mediobasal hypothalamus. The effects of synthetic ovine PrRP on prolactin secretion both in vitro and in vivo were also examined. In primary cultures of sheep pituitary
\end{abstract}

cells, PrRP significantly $(P<0 \cdot 01)$ increased prolactin concentrations in the culture medium but the response was not observed in every experiment and was only seen when pituitary glands were dispersed with collagenase rather than trypsin. PrRP was much less potent than TRH which caused a significant $(P<0 \cdot 01)$ two- to threefold increase in prolactin concentrations in every experiment. Intravenous (10 and $50 \mathrm{nmol}$ ) or intracerebroventricular (10 and $50 \mathrm{nmol}$ ) injection of PrRP had no significant effect on either plasma prolactin concentration or pulsatile LH secretion whereas intravenous injection of TRH $(10 \mathrm{nmol})$ produced a highly significant $(P<0 \cdot 01)$ and more than sevenfold stimulation of plasma prolactin concentrations. In conclusion, these results suggest that PrRP is unlikely to be an important prolactin-releasing factor in this species.

Journal of Endocrinology (2002) 174, 45-53

\section{Introduction}

Secretion of prolactin from the anterior pituitary gland is under dual control from inhibitory and stimulatory factors released from the median eminence or posterior pituitary gland. While it is generally accepted that dopamine is the major inhibitory factor, there is no consensus on the identity of physiologically relevant prolactin-releasing factors (PRF). Many putative PRFs have been identified and some of these have proven to be important in some species and under some physiological circumstances. However, there is no single neurochemical that is widely accepted as a PRF in the same way that gonadotrophinreleasing hormone, thyrotrophin-releasing hormone $(\mathrm{TRH})$, growth hormone-releasing hormone and corticotrophin-releasing hormone are recognised as releasing factors for the other anterior pituitary hormones. Within this context, the discovery of a novel peptide ligand for the human orphan G-protein-coupled receptor hGR3 (also known as UHR1 and GPR10) was of particular interest (Hinuma et al. 1998). This receptor is most abundantly expressed in the anterior pituitary gland
(Marchese et al. 1995, Welch et al. 1995) and so Hinuma et al. (1998) screened hypothalamic extracts after fractionation by HPLC for their ability to stimulate arachidonic acid turnover in $\mathrm{CHO}$ cells transfected with hGR3. Two peptides that were equipotent in this bioassay were isolated, a 31 amino acid form and an N-terminally truncated form with 20 amino acids. The long form of the peptide was further characterised and shown to stimulate prolactin secretion from rat pituitary cells in primary culture and $\mathrm{RC}-4 \mathrm{~B} / \mathrm{C}$ cells and was equipotent with TRH (Hinuma et al. 1998). Based on these observations, the peptide was named prolactin-releasing peptide (PrRP). Given the history of the PRF field, it is not surprising that subsequent studies by these and other authors have not provided convincing evidence in support of this role. For example, both in vivo and in vitro, PrRP has low potency in terms of its ability to stimulate prolactin secretion (Samson et al. 1998, Matsumoto et al. 1999, Jarry et al. 2000). Further, it is now known that the highest concentration of PrRP containing neurones is found in the brainstem (Minami et al. 1999) and that only small numbers of PrRP-positive neurones occur in the caudal dorsomedial hypothalamus 
(Minami et al. 1999). However, of more importance in relation to its proposed role as a PRF, PrRP immunoreactive fibres are not seen in the external zone of the median eminence (Maruyama et al. 1999).

To date, detailed studies of PrRP have focused mainly on the rat and little information is available for other species. As there are well-known differences between rats and other species in terms of the identity and potency of PRFs, the present investigation was undertaken to evaluate this peptide in female sheep. The aims of this study were as follows: first, to obtain a cDNA clone of sheep PrRP; secondly, to characterise the distribution of PrRP mRNA in the hypothalamus as well as other brain regions; thirdly, to determine whether PrRP stimulates prolactin secretion from sheep anterior pituitary cells in vitro; and fourthly, to determine whether intravenous or intracerebroventricular injection of PrRP stimulates prolactin or luteinising hormone (LH) secretion in vivo in the ewe.

\section{Materials and methods}

\section{Animals}

All experiments were conducted on mature Merino ewes housed indoors under a lighting regimen that followed the natural photoperiod. They were fed a maintenance diet and given free access to water. Tissue samples for extraction of RNA and tissue culture were obtained without regard for the stage of the oestrous cycle. Ewes were killed by intravenous injection of pentobarbitone and the brain and pituitary gland were quickly removed and dissected. Tissues for extraction of RNA were frozen on solid $\mathrm{CO}_{2}$ and stored at $-80{ }^{\circ} \mathrm{C}$. In vivo experiments were conducted on ewes that were ovariectomised 1-2 months beforehand. At the time of ovariectomy each ewe received a subcutaneous oestradiol implant $(1.0 \mathrm{~cm}$ ) (Anderson et al. 1996) that was removed 2 weeks before the 3 -week period during which the experiments were conducted. The lateral cerebral ventricle was chronically cannulated under anaesthesia as previously described (Sawangjaroen \& Curlewis 1994). During experiments, blood samples were collected from a jugular cannula that was inserted on the day preceding each experiment. Intravenous treatments were administered via the jugular cannula and intracerebroventricular injections were performed as previously described (Sawangjaroen \& Curlewis 1994). Procedures performed in this study were approved by the Animal Experimentation and Ethics Committee of The University of Queensland.

\section{Peptides/chemicals}

TRH was obtained from Auspep (Parkville, Australia). Ovine PrRP (oPrRP) was synthesised by Chiron Technologies (Clayton, Australia). Peptides were freshly prepared on the day of each experiment by dissolving them in sterile water.

\section{Cloning of oPrRP}

The nucleotide sequence of oPrRP cDNA was determined from clones obtained by reverse transcription (RT)polymerase chain reaction (PCR) followed by $3^{\prime}-$ and 5 '-rapid amplification of cDNA ends (RACE). Total RNA was extracted from the mediobasal hypothalamus (RT-PCR and $3^{\prime}$-RACE) or brainstem (5'-RACE) with Trizol reagent (Gibco BRL, Melbourne, Australia). For RT-PCR and cloning of the coding region, RNA from the mediobasal hypothalamus was reverse transcribed using the Superscript preamplification system according to the manufacturer's instructions (Gibco BRL). In brief, cDNA was synthesised from $5 \mu \mathrm{g}$ total RNA using an oligo(dT) primer $(1.25 \mu \mathrm{M})$ and Superscript II reverse transcriptase $(200 \mathrm{U})$. Reactions were treated with RNase $\mathrm{H}(2 \mathrm{U})$ prior to storage at $-80^{\circ} \mathrm{C}$. The $\mathrm{RT}$ product $(0.5 \mu \mathrm{l})$ was then used in PCR with forward (GCGGTG GGGGCCTGGCTC; primer i) and reverse (GAGGG CTCGGGAGGGCTCA; primer ii) primers designed from the published sequence of bovine PrRP (Hinuma et al. 1998). Each PCR contained 5\% dimethyl sulphoxide (DMSO), $0.5 \mu \mathrm{M}$ of each primer, $0.2 \mathrm{mM}$ dNTP, $2 \mathrm{mM}$ $\mathrm{MgCl}_{2}$ and $1.3 \mathrm{U}$ Taq DNA polymerase (Biotech International, Perth, Australia) in $50 \mu \mathrm{l} 1 \times$ Taq reaction buffer (Biotech International) and was carried out for 40 cycles $\left(94{ }^{\circ} \mathrm{C}, 30 \mathrm{~s} ; 68^{\circ} \mathrm{C}, 30 \mathrm{~s} ; 72{ }^{\circ} \mathrm{C}, 30 \mathrm{~s}\right)$. PCR products were visualised on an ethidium bromide-stained agarose gel, the band of interest was excised and the cDNA extracted and purified by ethanol precipitation. DNA fragments were ligated into the vector, pGEM-T (Promega, Madison, WI, USA) and transformed into JM109 competent cells (Promega). Plasmids containing the insert were prepared for automated sequencing using the ABI PRISM BigDye terminator cycle sequencing ready reaction kit (Perkin Elmer, Foster City, CA, USA) according to the manufacturer's instructions. Two clones were sequenced in both directions.

\section{$3^{\prime}-R A C E$}

cDNA was synthesised from $5 \mu \mathrm{g}$ total RNA using $1.88 \mu \mathrm{M}$ RACE RT primer (GACCACGCGTATCG ATGTCGACTTTTTTTTTTTTTTTT; primer iii) and superscript II reverse transcriptase (200 U). A modification for $\mathrm{RT}$ on $\mathrm{GC}$-rich sequences was used as follows: a higher incubation temperature $\left(50^{\circ} \mathrm{C}\right.$ instead of $42{ }^{\circ} \mathrm{C}$ ) was used during cDNA synthesis, the RNA/primer mix was directly shifted from $70{ }^{\circ} \mathrm{C}$ to $50^{\circ} \mathrm{C}$ and the complete $2 \times$ reaction mix was prewarmed to $50{ }^{\circ} \mathrm{C}$ before adding it to the RNA/primer mix. Following RT, the reaction was treated with RNase $\mathrm{H}(2 \mathrm{U})$ prior to storage at $-80{ }^{\circ} \mathrm{C}$. The RT product ( $1 \cdot 0 \mu$ l of 1:10 dilution) was used in first 
round PCR $\left(94{ }^{\circ} \mathrm{C}, 30 \mathrm{~s} ; 60{ }^{\circ} \mathrm{C}, 30 \mathrm{~s} ; 72{ }^{\circ} \mathrm{C}, 30 \mathrm{~s} ; 30\right.$ cycles) with an oPrRP forward primer (CTGGCTCCT CTGCCTGCTGCT; primer iv), based on the sequence obtained above, and a reverse RACE-anchor primer (GACCACGCGTATCGATGTCGAC; primer v). This was followed by partially nested, second round PCR $\left(94{ }^{\circ} \mathrm{C}, 30 \mathrm{~s} ; 58{ }^{\circ} \mathrm{C}, 30 \mathrm{~s} ; 72{ }^{\circ} \mathrm{C}, 30 \mathrm{~s} ; 35\right.$ cycles) using primer $\mathrm{v}$ and primer vi (GCAGAGCCCACCAGCA CTCCAT). Cloning and sequencing of the PCR product was performed as described above.

\section{$5^{\prime}-R A C E$}

cDNA was synthesised using the Superscript preamplification system with an oligo(dT) primer as described above and then purified using a QIAquick PCR purification kit (QIAGEN, Victoria, Australia), eluted with $30 \mu \mathrm{l}$ water, and ligated to the RACE A primer $\left(\mathrm{PO}_{4}\right.$-GTAGGAA TTCGGGTTGTAGGGAGGTGACATTGCC; primer vii) as follows: $20 \mu \mathrm{l}$ cDNA and $10 \mu \mathrm{l}$ of $10 \mu \mathrm{M}$ RACE A primer were heated to $60{ }^{\circ} \mathrm{C}$ for $5 \mathrm{~min}$ and then chilled on ice. T4 RNA ligase $(30 \mathrm{U})$ and $3.5 \mu \mathrm{l} 10 \times \mathrm{T} 4 \mathrm{RNA}$ ligase buffer (Genesearch, Arundel, Australia) were added and the reaction left at room temperature $\left(22-24{ }^{\circ} \mathrm{C}\right)$ overnight. Ligated cDNA was purified using the QIAquick PCR purification kit and eluted in $40 \mu \mathrm{l}$ water. cDNA $(5 \mu \mathrm{l})$ was used as template in PCR with $0 \cdot 1 \mu \mathrm{M}$ RACE B primer (GGCAATGTCGACCTCCCTAC AAC; primer viii) and a gene-specific primer (GTCGCT TGTGGAGGAGGAGGGATG; primer ix), 5\% DMSO, $2 \mathrm{mM} \mathrm{MgCl}_{2}, 0.2 \mathrm{mM} \mathrm{dNTP}$ and $1.3 \mathrm{U}$ Taq DNA Polymerase (Biotech International) in $50 \mu \mathrm{l} 1 \times$ Taq reaction buffer (Biotech International). This was carried out for 25 cycles $\left(94{ }^{\circ} \mathrm{C}, 60 \mathrm{~s} ; 80{ }^{\circ} \mathrm{C}, 60 \mathrm{~s} ; 60{ }^{\circ} \mathrm{C}, 60 \mathrm{~s} ; 68^{\circ} \mathrm{C}\right.$, $5 \mathrm{~min} ; 94^{\circ} \mathrm{C}, 30 \mathrm{~s} ; 60^{\circ} \mathrm{C}, 30 \mathrm{~s} ; 68^{\circ} \mathrm{C}, 2 \mathrm{~min} ; 68^{\circ} \mathrm{C}$, $30 \mathrm{~min})$. The product $(2 \mu \mathrm{l})$ was used in a second PCR with $0 \cdot 2 \mu \mathrm{M}$ RACE C primer (CTCCCTACAACCCG AATTCCTAC; primer $\mathrm{x}$ ) and a gene-specific primer (GAGGGGTCGGGAGGGCTCA; primer xi) for 35 cycles $\left(94{ }^{\circ} \mathrm{C}, 60 \mathrm{~s} ; 94{ }^{\circ} \mathrm{C}, 20 \mathrm{~s} ; 62{ }^{\circ} \mathrm{C}, 40 \mathrm{~s} ; 68{ }^{\circ} \mathrm{C}, 2 \mathrm{~min}\right.$; $68^{\circ} \mathrm{C}, 30 \mathrm{~min}$ ) and the product was visualised on an ethidium bromide-stained agarose gel. A band of 400-500 bases was excised and the DNA extracted using the CONCERT rapid gel extraction system (Gibco BRL), cloned and sequenced as described above.

In order to confirm the assembled sequence and to determine whether the same sequence occurred in both mediobasal hypothalamus and brainstem, primers to the 5'- (GCTCCCGTCCAGAGCACTCGCCAG; primer xii) and $3^{\prime}$-untranslated regions (UTRs; primer vii) were used in PCR and the resulting bands were excised, purified, cloned and sequenced as described above.

\section{Distribution of $\operatorname{Pr} R P \operatorname{mRN} A$}

Northern analysis Total RNA was extracted from the dorsomedial and lateral brainstems, mediobasal hypothalamus and liver as described above. A $124 \mathrm{bp}$ cDNA probe to the $3^{\prime}$-UTR was subcloned from the 3'-RACE clone by PCR with primers xiii (CTGGGG CGGCTGACA) and xiv (TTTTTTTTGAACAAGCC AGC). Following a restriction digest of plasmid DNA with NcoI and NdeI, the probe was purified by agar gel electrophoresis. The cDNA probe was labelled with $5 \mu \mathrm{l} \quad\left[\alpha_{-}{ }^{32} \mathrm{P}\right]-\mathrm{dCTP} \quad(110 \quad \mathrm{TBq} / \mathrm{mmol} ;$ Amersham International plc, Amersham, Bucks, UK) using the random prime DNA labelling kit (Amersham International plc) and purified from unincorporated nucleotides using a Sephadex G-50 column (nick column; Amersham International plc). RNA was denatured and separated on a $2 \cdot 4 \%$ formaldehyde $/ 1 \cdot 2 \%$ agarose gel, transferred overnight to a Hybond XL membrane (Amersham International plc) by capillary transfer in $20 \times$ SSC buffer $(3 \mathrm{M} \mathrm{NaCl}, 300 \mathrm{mM}$ sodium citrate dihydrate, $\mathrm{pH} 7 \cdot 8$ ) and UV-cross linked (UV Stratalinker; Stratagene, San Diego, CA, USA). Hybridisation was carried out for $18 \mathrm{~h}$ at $42{ }^{\circ} \mathrm{C}$ in Ultrahyb solution (Ambion, Austin, TX, USA), containing 50\% formamide, followed by two washes for $15 \mathrm{~min}$ at $65^{\circ} \mathrm{C}$ in $1 \times \mathrm{SSC}$, $0 \cdot 1 \%$ SDS followed by $10 \mathrm{~min}$ at $65^{\circ} \mathrm{C}$ in $0 \cdot 1 \times$ SSC, $0 \cdot 1 \%$ SDS. The membrane was exposed to Hyperfilm MP autoradiographic film (Amersham International plc) for 7 days at $-80{ }^{\circ} \mathrm{C}$ with an intensifying screen.

RT-PCR Brain areas were dissected with a scalpel blade and frozen on solid $\mathrm{CO}_{2}$. RT-PCR was performed as described above. PCR for PrRP was performed using primers $i$ and ii for 35 cycles in the presence of 5\% DMSO $\left(94{ }^{\circ} \mathrm{C}, 30 \mathrm{~s} ; 68^{\circ} \mathrm{C}, 30 \mathrm{~s} ; 72{ }^{\circ} \mathrm{C}, 30 \mathrm{~s}\right)$. In addition, PCR with ovine $\beta$-actin primers (GCTGTGCTGTCCCTGT ACGC and GCGGATGTCGACGTCACAC) was performed $\left(94{ }^{\circ} \mathrm{C}, 30 \mathrm{~s} ; 68{ }^{\circ} \mathrm{C}, 30 \mathrm{~s} ; 72{ }^{\circ} \mathrm{C}, 30 \mathrm{~s} ; 24\right.$ cycles; no DMSO) as a positive control for each tissue sample.

\section{In vitro experiments}

Two techniques were used for primary culture of sheep pituitary cells. The first method which uses trypsin $(5 \mathrm{mg} / \mathrm{ml})$ to disperse the cells has been used extensively in this laboratory (Sawangjaroen et al. 1996, 1997, Colthorpe et al. 2000). Dispersed cells were plated into 24-well plates (Nunclon Multidish; Nalge Nunc, Naperville, IL, USA), at a density of 500000 cells/well and preincubated for 4 days in Dulbecco's modification of Eagle's medium (DMEM-I; ICN, Aurora, OH, USA) supplemented with $10 \%$ fetal calf serum (Gibco BRL; FCS-DMEM-I) at $37{ }^{\circ} \mathrm{C}$ under $5 \% \mathrm{CO}_{2}$ in air. The culture medium was replaced after 3 days. On the day of the experiment, each well was washed twice with Dulbecco's phosphate-buffered saline (PBS; Gibco BRL) containing $\mathrm{CaCl}_{2} \cdot 2 \mathrm{H}_{2} \mathrm{O}(0 \cdot 9 \mathrm{mmol} / \mathrm{l})$ and $\mathrm{MgCl}_{2} \cdot 6 \mathrm{H}_{2} \mathrm{O}$ $(0.5 \mathrm{mmol} / \mathrm{l})$, once with $0.2 \%$ bovine serum albuminDMEM-I (BSA-DMEM-I) and then preincubated in 
$1 \mathrm{ml}$ BSA-DMEM-I for $30 \mathrm{~min}$. The medium was then replaced with a further $1 \mathrm{ml}$ BSA-DMEM-I and incubated for another hour, after which the incubation medium was removed. Each well then received BSADMEM-I containing the test compounds. The cells were incubated for a further $2 \mathrm{~h}$ and then the medium was removed and stored at $-20{ }^{\circ} \mathrm{C}$.

The second method which uses collagenase and pancreatin to disperse the cells was based on a recent study by Kawamata et al. (2000) on rat pituitary cells in which it was claimed that this method produces cells that are more responsive to PrRP than those prepared by trypsin digestion. In brief, pituitary glands were washed in buffer containing Dulbecco's PBS containing HEPES (25 mmol/l), penicillin G (100 $000 \mathrm{U} / \mathrm{l})$ and streptomycin $(100 \mathrm{mg} / \mathrm{l}), \mathrm{pH} 7 \cdot 4$ (DPBS-II) and then cut into small pieces about 1-2 mm square which were then washed six to eight times in the same buffer. The pieces from two pituitary glands were then incubated with gentle stirring at $37^{\circ} \mathrm{C}$ for $90 \mathrm{~min}$ in $30 \mathrm{ml}$ DPBS-II containing $0 \cdot 2 \%$ collagenase A (Boehringer Mannheim, Mannheim, Germany), $20 \mathrm{mg} / 1$ DNase (Sigma Chemical Co., St Louis, MO, USA), 0.4\% BSA (Sigma Chemical Co.) and $0 \cdot 2 \%$ glucose. After gentle trituration through a glass pipette, cells were centrifuged and the pellet resuspended in DPBS-II $(20 \mathrm{ml})$ containing pancreatin $(0 \cdot 25 \%$; Sigma Chemical Co.) and DNase $(20 \mathrm{mg} / \mathrm{l})$ and incubated for 8 min at $37^{\circ} \mathrm{C}$. FCS (10\% final concentration) was then added, the cells centrifuged and washed twice in DMEM containing $\mathrm{NaHCO}_{3}(3.7 \mathrm{~g} / \mathrm{l}), 20 \mathrm{mmol} / \mathrm{l}$ HEPES, penicillin $\mathrm{G}(100000 \mathrm{U} / \mathrm{l})$ and streptomycin $(100 \mathrm{mg} / \mathrm{l})$, $\mathrm{pH} 7 \cdot 4$ and 10\% FCS (FCS-DMEM-II) and then filtered through a nylon mesh (Beckton Dickinson, Bedford, MA, USA). Dispersed cells were plated into 24-well plates at a density of 150000 cells/well and were preincubated for 4 days in FCS-DMEM-II as described above. The culture medium was replaced after 3 days. On the day of the experiment, cells were washed three times with $1 \mathrm{ml}$ DMEM containing $3.7 \mathrm{~g} / 1 \mathrm{NaHCO}_{3}, 20 \mathrm{mmol} / 1$ HEPES and $0 \cdot 2 \% \mathrm{BSA}, \mathrm{pH} 7 \cdot 4$ (DMEM-III) and then incubated for $1 \mathrm{~h}$ in the same culture medium. Each well was then washed twice with about $0.5 \mathrm{ml}$ DMEM-III and then the test substance in $1 \mathrm{ml}$ DMEM-III was added and incubated for $2 \mathrm{~h}$ at $37^{\circ} \mathrm{C}$ after which the medium was removed and stored at $-20{ }^{\circ} \mathrm{C}$.

For each of the three experiments reported here, pituitary glands from two ewes were pooled and processed together. In two of the three experiments, the pooled pituitary pieces were then divided into two parts which were processed by each of the above methods. All treatments with peptide or vehicle were done in quadruplicate.

In vivo experiments

Intravenous treatments with PrRP and TRH Six ovariectomised ewes were treated with vehicle $(1 \mathrm{ml}$ water) or PrRP (10 and $50 \mathrm{nmol}$ ) administered intravenously through a jugular cannula. All animals received each treatment on successive days with treatments organized in a Latin square design (Sokal \& Rohlf 1995). Blood samples were collected every $10 \mathrm{~min}$ for $3 \mathrm{~h}$ before and $3 \mathrm{~h}$ after injection of peptides. In a separate experiment on six ewes, the prolactin response to $10 \mathrm{nmol}$ TRH (Auspep) was also determined. Plasma was stored frozen for assay of prolactin (selected samples) and LH (50 nmol PrRP treatment and vehicle only).

Intracerebroventricular PrRP The six animals from the above study were then used to test for central effects of PrRP. Each animal received intracerebroventricular vehicle $(200 \mu \mathrm{l}$ water) or PrRP (10 and $50 \mathrm{nmol}$ ) with treatments again organized in a Latin square design. Blood sampling was as described above and again prolactin was measured in selected samples and LH was measured in all samples.

\section{Radioimmunoassay, LH pulse analysis and statistics}

Prolactin concentrations in culture medium or plasma and LH concentrations in plasma were determined by radioimmunoassay as previously described (Sawangjaroen \& Curlewis 1994). Prolactin assay sensitivity was $0 \cdot 8 \mathrm{ng} / \mathrm{ml}$ and the intra- and interassay coefficients of variation were $7 \cdot 2$ and $16 \cdot 3 \%$. Sensitivity for the LH assay was $0 \cdot 2 \mathrm{ng} / \mathrm{ml}$ and the intra- and interassay coefficients of variation were $11 \cdot 3$ and $16 \cdot 6 \%$. Plasma LH concentrations during the 3-h periods before and after administration of treatments were analysed for pulsatility using the Munro program as previously described (Anderson et al. 1996).

In each in vitro experiment, the response to PrRP or TRH was examined by analysis of variance (ANOVA) with Duncan's multiple range test for post-hoc comparisons with control. Overall effects (three experiments for the collagenase method or two experiments for the trypsin method) were examined by nested ANOVA. For the in vivo experiments, repeat measure ANOVA was used to analyse pre- and post-treatment windows for effects on plasma hormone concentrations. LH pulse characteristics for each treatment window were analysed by one-way ANOVA.

\section{Results}

\section{Cloning}

The assembled sequence obtained from PCR followed by $3^{\prime}$ - then $5^{\prime}$ - RACE is shown in Fig. 1. PCR/cloning with primers to the $5^{\prime}-$ and $3^{\prime}$-UTRs confirmed that this sequence occurred in both the mediobasal hypothalamus and brainstem. The $461 \mathrm{bp}$ sequence was characterised by short $5^{\prime}$ - and $3^{\prime}$-UTRs of 84 and $80 \mathrm{bp}$ respectively 


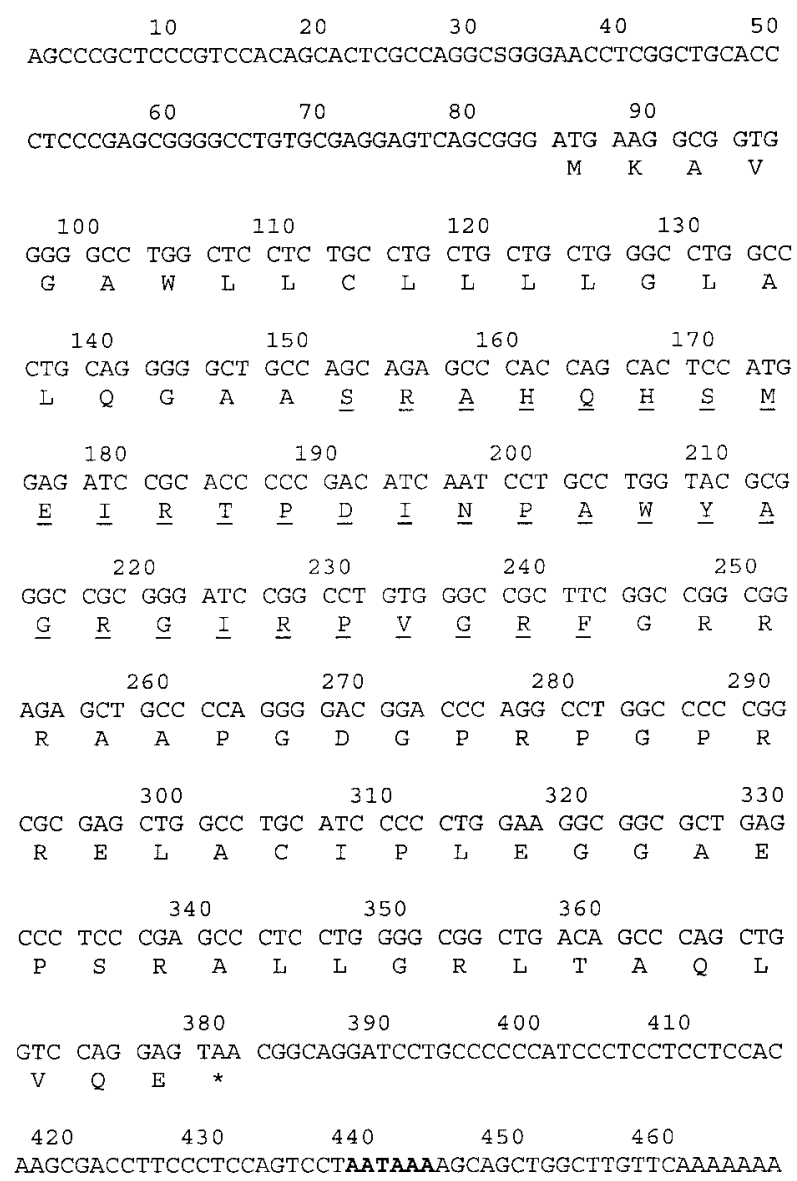

Figure 1 Nucleotide and deduced amino acid sequence for ovine PrRP mRNA. The sequence of mature peptide (PrRP31) is underlined. The polyadenylation signal is shown in bold. GenBank accession number, AF450453.

(excluding the poly-A tail) and a $297 \mathrm{bp}, \mathrm{GC}-$ rich (71\%), coding region. Analysis of the $3^{\prime}$-UTR indicated a single polyadenylation signal (AATAAA) $58 \mathrm{bp}$ downstream of the stop codon, followed by the polyadenylation site a further $16 \mathrm{bp}$ downstream. Over the entire coding region, the oPrRP nucleotide sequence had $95.6 \%$ identity with the published sequence for bovine PrRP (Hinuma et al. 1998). The deduced amino acid sequence for the 31 amino acid oPrRP was identical to that of bovine PrRP and only five residues differed over the full 98 residue prohormone.

\section{$\operatorname{PrRP} m R N A$ distribution}

Figure 2 shows a Northern blot of hypothalamus and lateral and dorsomedial brainstem hybridised with a cDNA probe to the $3^{\prime}$-UTR of oPrRP. A single transcript of about $590 \mathrm{bp}$ is present in the dorsomedial brainstem. Very faint bands of the same size were present in the lateral

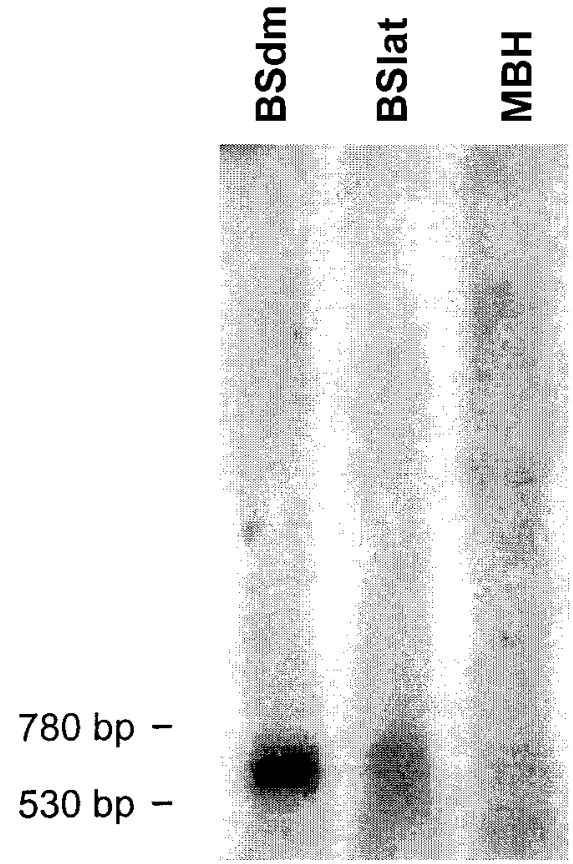

Figure 2 Northern blot of total RNA from sheep tissues hybridized to a cDNA probe corresponding to the $3^{\prime}$-UTR of oPrRP. BSdm, dorsomedial brainstem (10 $\mu \mathrm{g}$ RNA); Bslat, lateral brainstem $(10 \mu \mathrm{g}$ $\mathrm{RNA}) ; \mathrm{MBH}$, mediobasal hypothalamus (15 $\mu \mathrm{g}$ RNA).

brainstem and hypothalamus although these cannot be seen in Fig. 2. RT-PCR was used to give a more detailed picture of the PrRP mRNA distribution in various hypothalamic and brainstem regions. In the hypothalamus and surrounding structures (Fig. 3, top panels), the most abundant signal was seen in the ventromedial hypothalamic region with faint bands also detected in dorsomedial hypothalamus, lateral hypothalamus, arcuate nucleus/median eminence and anterior hypothalamus. No product was obtained from the anterior pituitary gland or caudate nucleus. In the brainstem (Fig. 3, bottom panels), intense bands can be seen for dorsomedial and lateral brainstem but not for the ventromedial brainstem. In this PCR, which was optimised for semi-quantitative comparison between tissues expressing PrRP mRNA, a weak signal was obtained from both the rostral and caudal mediobasal hypothalamus but not the mammillary bodies or in the water negative control. When the Superscript enzyme was omitted from the RT reaction, no PCR products were obtained for any region.

\section{In vitro experiments}

When pituitary cells were prepared by the trypsin digestion method, oPrRP did not cause a significant increase in prolactin concentrations in the culture medium whereas TRH resulted in a greater than twofold increase in prolactin $(P<0 \cdot 01$; results not shown $)$ with a maximal 

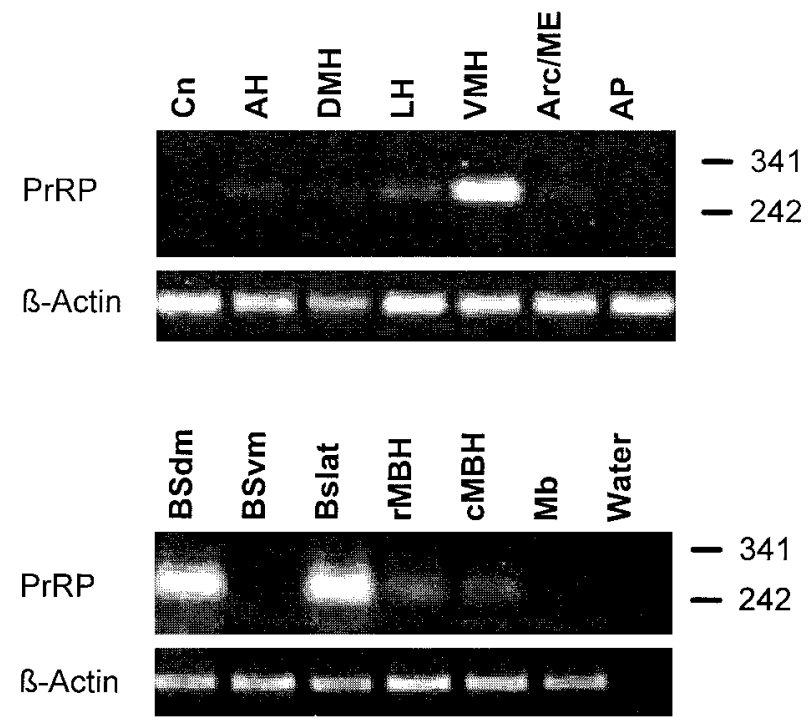

Figure 3 RT-PCR of sheep tissues with primers to the coding region of oPrRP and $\beta$-actin. $\mathrm{Cn}$, caudate nucleus; $\mathrm{AH}$, anterior hypothalamic region; $\mathrm{DMH}$, dorsomedial hypothalamic region; $\mathrm{LH}$, lateral hypothalamic region; $\mathrm{VMH}$, ventromedial hypothalamic region; Arc/ME, arcuate nucleus and median eminence; $\mathrm{AP}$, anterior pituitary gland; BSdm, dorsomedial brainstem; BSvm, ventromedial brainstem; Bslat, lateral brainstem; $\mathrm{rMBH}$, rostral mediobasal hypothalamus; $\mathrm{CMBH}$, caudal mediobasal hypothalamus; Mb, mammillary bodies. PCR products were electrophoresed on a $1 \cdot 5 \%$ agarose gel and visualised with ethidium bromide. response at $10 \mathrm{nmol} / 1$. Cells prepared by the collagenase method did show a prolactin response to oPrRP in two out of three experiments. Overall analysis of the three experiments by nested ANOVA revealed a highly significant $(P<0 \cdot 01)$ effect of oPrRP which was due to increased prolactin concentrations in response to 10 and $100 \mathrm{nmol} / 1$ PrRP in one experiment and at $10 \mathrm{nmol} / 1$ and $1 \mu \mathrm{mol} / \mathrm{l}$ PrRP in another. In the third experiment, PrRP had no significant effect on prolactin. Again, TRH caused a twoto threefold increase in prolactin concentrations $(P<0 \cdot 01)$ in all experiments with a maximal response at $1 \mathrm{nmol} / 1$. Examples of the prolactin responses to PrRP and TRH for one of the three experiments are shown in Fig. 4.

\section{In vivo experiments}

In the period from 10 to $180 \mathrm{~min}$ after intravenous injection of oPrRP (10 and $50 \mathrm{nmol}$ doses), plasma prolactin concentrations were not significantly different from those after vehicle injection. Table 1 shows prolactin concentrations in the period immediately before and after injection. In contrast, immediately after injection of TRH $(10 \mathrm{nmol})$, prolactin concentrations were significantly $(P<0 \cdot 01)$ increased (Table 1$)$ and remained above those following vehicle control injections for the entire sampling period (180 min; results not shown). Intracerebroventricular injection of PrRP also had no effect on plasma prolactin concentrations (Table 1) or pulsatile $\mathrm{LH}$ secretion (Table 2).
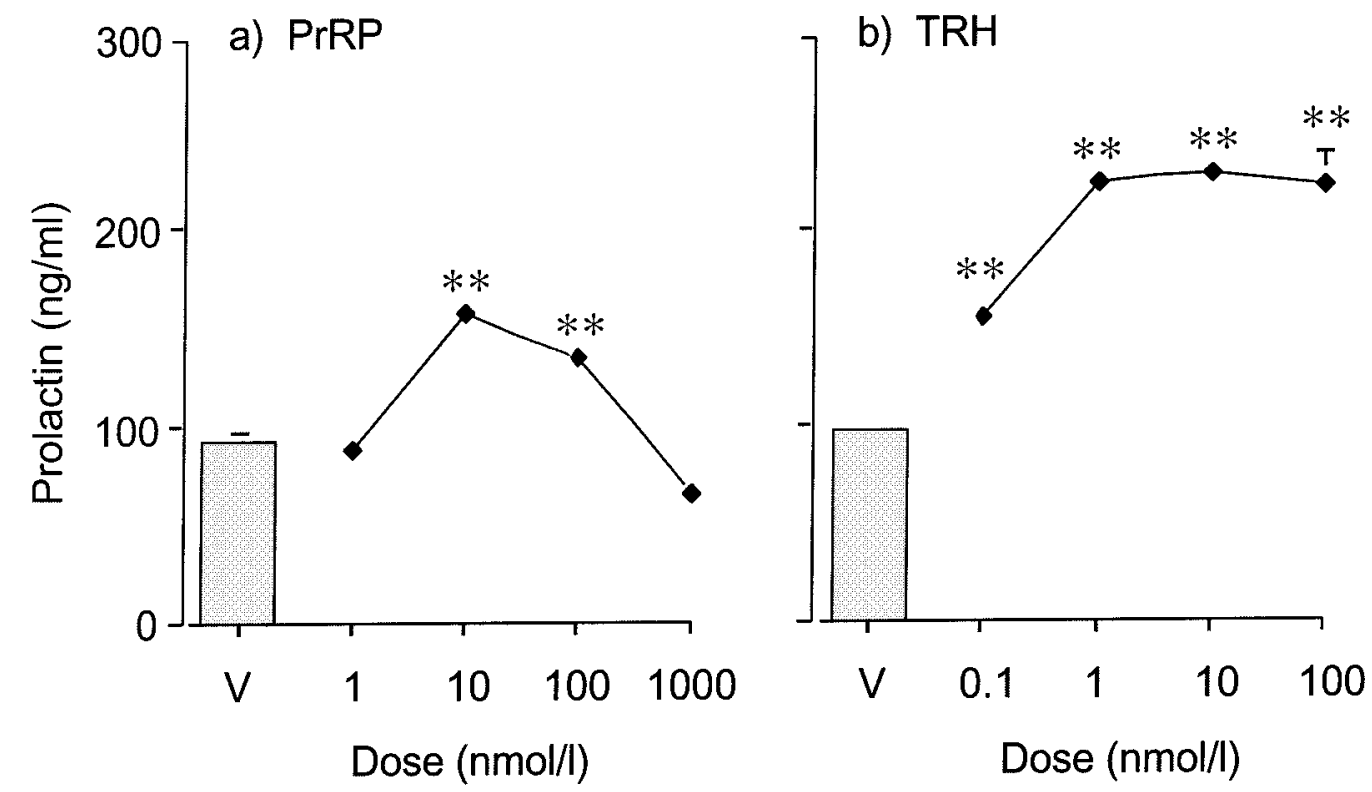

Figure 4 Effects of (a) oPrRP and (b) TRH on prolactin concentrations in culture medium from primary cultures of sheep pituitary cells following a 2 -h incubation. Results are the means \pm S.E.M. $(n=4) .{ }^{*} P<0 \cdot 01$ compared with control. 
Table 1 Plasma prolactin concentrations $(\mathrm{ng} / \mathrm{ml})$ following intravenous and intracerebroventricular injection of PrRP and intravenous injection of TRH. Results are given as means \pm S.E.M. $(n=6)$

\begin{tabular}{|c|c|c|c|c|}
\hline & $-20 \mathrm{~min}$ & $\mathbf{0}$ & $10 \mathrm{~min}$ & $20 \mathrm{~min}$ \\
\hline \multicolumn{5}{|c|}{ Intravenous injection } \\
\hline Vehicle & $25 \cdot 0 \pm 11 \cdot 1$ & $21 \cdot 4 \pm 7 \cdot 5$ & $19 \cdot 9 \pm 7 \cdot 0$ & $20 \cdot 2 \pm 6 \cdot 5$ \\
\hline $\operatorname{PrRP}(10 \mathrm{nmol})$ & $23 \cdot 0 \pm 4 \cdot 7$ & $23 \cdot 7 \pm 4 \cdot 0$ & $23 \cdot 0 \pm 3 \cdot 5$ & $19 \cdot 6 \pm 2 \cdot 9$ \\
\hline $\operatorname{PrRP}(50 \mathrm{nmol})$ & $23 \cdot 1 \pm 5 \cdot 9$ & $19 \cdot 8 \pm 5 \cdot 1$ & $19 \cdot 4 \pm 4 \cdot 4$ & $17 \cdot 5 \pm 3 \cdot 4$ \\
\hline Vehicle & $47 \cdot 9 \pm 8 \cdot 3$ & $49 \cdot 0 \pm 7 \cdot 8$ & $45 \cdot 5 \pm 8 \cdot 6$ & $46 \cdot 9 \pm 9 \cdot 8$ \\
\hline TRH $(10 \mathrm{nmol})$ & $55 \cdot 1 \pm 7 \cdot 4$ & $46 \cdot 1 \pm 5 \cdot 1$ & $328 \cdot 3 \pm 34^{* *}$ & $327 \cdot 4 \pm 31 \cdot 5^{\text {** }}$ \\
\hline \multicolumn{5}{|c|}{ Intracerebroventricular injection } \\
\hline Vehicle & $13 \cdot 4 \pm 4 \cdot 1$ & $13 \cdot 3 \pm 3 \cdot 3$ & $16 \cdot 7 \pm 4 \cdot 4$ & $15 \cdot 8 \pm 4 \cdot 7$ \\
\hline $\operatorname{PrRP}(10 \mathrm{nmol})$ & $12 \cdot 3 \pm 4 \cdot 8$ & $15 \cdot 8 \pm 5 \cdot 7$ & $15 \cdot 8 \pm 4 \cdot 5$ & $13 \cdot 6 \pm 4 \cdot 1$ \\
\hline $\operatorname{PrRP}(50 \mathrm{nmol})$ & $14 \cdot 9 \pm 3 \cdot 9$ & $17 \cdot 7 \pm 3 \cdot 2$ & $18 \cdot 7 \pm 3 \cdot 4$ & $15 \cdot 9 \pm 2 \cdot 9$ \\
\hline
\end{tabular}

${ }^{*} P<0 \cdot 01$ compared with 0 min.

\section{Discussion}

Since its discovery by Hinuma et al. (1998), few studies have provided strong evidence in support of a role for PrRP as a PRF. The present study in sheep is the first detailed investigation of this peptide in a species other than the rat and shows that PrRP has only a weak stimulatory effect on prolactin secretion in vitro and is much less potent than TRH. In vivo, PrRP had no effect on plasma prolactin or LH secretion. Further, the distribution of mRNA for PrRP suggests that, as in the rat, this peptide is likely to be involved in functions unrelated to the regulation of anterior pituitary gland function.

In their original publication on PrRP, Hinuma et al. (1998) used dispersed anterior pituitary cells from lactating rats in static culture and showed that PrRP and TRH were equipotent in terms of their ability to stimulate prolactin secretion. In a later study by this group (Kawamata et al. 2000), it was shown that cells obtained from lactating rats were more responsive to PrRP than those obtained from random cycling rats. Nevertheless, a highly significant effect of PrRP was observed in the cells

Table $2 \mathrm{LH}$ pulse characteristics in the 3 -h periods before and after intracerebroventricular injection of oPrRP. Results are given as means \pm S.E.M. $(n=6)$

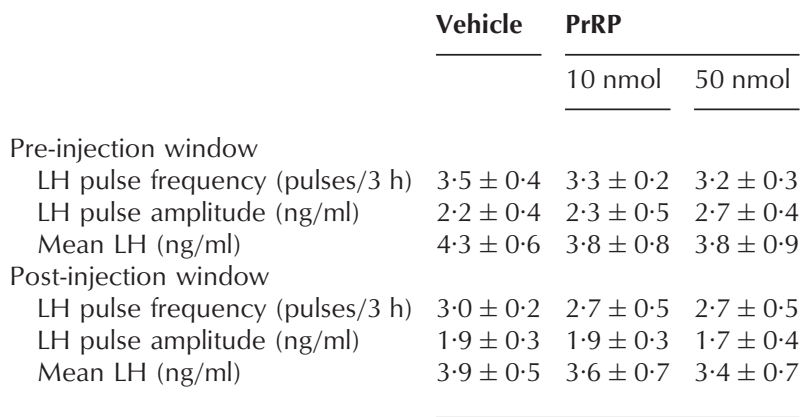

from random cycling rats with prolactin concentrations in culture medium increasing to between 130 and 160\% of control. They also showed that PrRP was effective in pituitary cells from male rats but that the prolactin response was enhanced by prior treatment with oestrogen. In contrast to these studies, Samson et al. (1998) obtained poor responses to PrRP in pituitary cells obtained from random cycling rats and no response in cells prepared from male rats. Methodological differences between these two laboratories could explain the experimental differences. For example, Kawamata et al. (2000) have shown that preincubation for 4 days rather than for 1 day in FCSDMEM markedly enhances the responsiveness of anterior pituitary cells to PrRP relative to TRH. This group also claims that dispersion of cells with collagenase rather than trypsin is necessary in order to maximise responsiveness to PrRP (S Hinuma, personal communication). These details are of note because Samson et al. (1998) used trypsin dispersion and preincubated their cells for only 3 days, which could explain the poor responses to PrRP compared with TRH. In the present study of sheep pituitary cells, we compared our standard trypsin dispersion method with a modification of the collagenase method used by Kawamata et al. (2000) and, in both procedures, cells were preincubated for 4 days before treatment with peptides. Consistent with the above discussion, we only observed significant stimulation of prolactin secretion when the collagenase dispersion method was used. Clearly the trypsin and collagenase methods differed in several ways in addition to the enzyme preparations used and we made no attempt to identify the critical factor(s) associated with increasing the responsiveness to PrRP. In other experiments not reported here, we tested rat PrRP supplied by Dr S Hinuma (Takeda Chemical Industries, Ibaraki, Japan) and oPrRP sourced from another company (Phoenix Pharmaceuticals, Belmont, CA, USA) and again found no effect on prolactin secretion, even though TRH increased prolactin concentrations more than twofold. 
Experiments done on primary cultures of rat anterior pituitary cells (Kawamata et al. 2000) indicate that the 2 amino acid difference between rat and bovine/ovine PrRPs does not affect biological activity. Together, these results suggest that PrRP is not a potent PRF in sheep although further studies on cells obtained from ewes in the follicular phase, following oestrogen treatment and during lactation are required to clarify this issue.

Given the low potency of PrRP in our in vitro experiments, it is perhaps not surprising that we saw no effect on plasma prolactin concentrations following intravenous injection of $50 \mathrm{nmol} \operatorname{PrRP}$ (about $1.2 \mathrm{nmol} / \mathrm{kg}$ ). It is important to note that, in rats, doses of 50 and $500 \mathrm{nmol} / \mathrm{kg}$ in females and males respectively are required to stimulate plasma prolactin secretion (Matsumoto et al. 1999) and so it remains possible that similar dose rates on a per $\mathrm{kg}$ basis may affect prolactin secretion in sheep. However, in comparison, both in rats (Jarry et al. 2000) and sheep (present study), low doses of TRH cause a marked stimulation of prolactin secretion, clearly indicating that PrRP has relatively low potency in both species. In the rat, GR3, the putative PrRP receptor, is abundantly expressed in the anterior pituitary gland (Welch et al. 1995, Hinuma et al. 1998), although more recent studies also show that receptor protein and mRNA are present at higher levels in the reticular thalamic nucleus and periventricular hypothalamus than in the anterior pituitary gland (Roland et al. 1999). Clearly, further studies are required to determine the role of this receptor in the anterior pituitary gland.

We also tested for centrally mediated effects of PrRP on prolactin and LH secretion following intracerebroventricular injection but again no effects were observed. Of interest in this regard, Seal et al. (2000) have reported a significant stimulatory effect of PrRP on plasma LH and follicle-stimulating hormone in male rats following intracerebroventricular injection. Further, in female rats treated with oestrogen, central injection of anti-PrRP serum suppresses the LH and prolactin surges (Hizume et al. 2000). Clearly, further studies of both rats and sheep are required to determine whether there are major species differences in the roles of PrRP that can account for these different responses.

In the present study, a single transcript for PrRP of about $590 \mathrm{bp}$ was detected by Northern blot. In contrast, the assembled oPrRP cDNA sequence obtained by $3^{\prime}, 5^{\prime}$-RACE was only $461 \mathrm{bp}$ but this difference is presumably due to the poly-A tail. The cDNA structure of oPrRP is similar to that reported for rat PrRP (Yamada et al. 2001). The rat PrRP gene spans about $2.4 \mathrm{~kb}$ and contains three exons and two introns. In the present study, we did not determine the genomic sequence, but the oPrRP gene most likely also contains introns because PCR of genomic DNA yields a higher molecular weight product than expected from the cDNA sequence (authors' unpublished observation). This observation also indicated that RT-PCR products obtained in this present study are derived from processed mRNA. Another interesting feature of the PrRP gene, in both rat and sheep, is the relatively short length of the UTRs. In particular the small size of the 3'-UTR may be important in increasing mRNA stability (Tanguay \& Gallie 1996).

In the rat, PrRP is most abundantly expressed in the brainstem where both mRNA and protein have been localised to the caudal part of the nucleus of the solitary tract and the caudal ventrolateral medulla (Chen et al. 1999, Minami et al. 1999). In our Northern blot and RT-PCR experiments performed on sheep tissues, the strongest signals were obtained from the dorsomedial followed by the lateral brainstem which, respectively, include these regions. As in the rat, the level of expression in the sheep hypothalamus was much lower than in brainstem as illustrated by the Northern blot (Fig. 2) and RT-PCR (Fig. 3, lower panel). Within the hypothalamus, we obtained a strong RT-PCR signal from the ventromedial region which excluded most of the arcuate nucleus and lateral hypothalamus. When we divided the mediobasal hypothalamus into rostral and caudal regions which were separated at the caudal margin of the infundibular stalk, we observed signals of similar intensity from the two regions. This finding suggests a more extensive distribution of PrRP in the sheep compared with rat hypothalamus in which expression is localised to a small region in the caudal hypothalamus, identified as the caudal dorsomedial hypothalamus (Minami et al. 1999). However in our experiments on the rat hypothalamus in which the brain micropunch technique was combined with quantitative RT-PCR, we detected a greater level of PrRP mRNA expression in the ventromedial hypothalamic nucleus, predominantly within the dorsomedial division, than in the caudal dorsomedial hypothalamus (S T Anderson, T Lang, I C Kokay, D R Grattan \& J D Curlewis; unpublished results) which is where PrRP mRNA and peptide have been localised by Minami et al. (1999).

In conclusion, our results have indicated that PrRP is expressed in the ventromedial hypothalamus and brainstem of sheep. Experiments conducted in vivo and in vitro do not support a role for this peptide in the regulation of either prolactin or $\mathrm{LH}$ secretion in this species.

\section{Acknowledgements}

The authors thank Anna Thomas and Julian Nalliah for technical assistance, the National Institute of Diabetes and Digestive and Kidney Disease's National Hormone and Peptide Program and Dr A F Parlow for the gift of purified hormones for radioimmunoassay. This research was funded by the National Health and Medical Research Council of Australia and the Australian Research Council Small Grants Scheme. 


\section{References}

Anderson ST, Sawangjaroen K \& Curlewis JD 1996 Pituitary adenylate cyclase-activating polypeptide acts within the medial basal hypothalamus to inhibit prolactin and luteinizing hormone secretion. Endocrinology 137 3424-3429.

Chen C, Dun SL, Dun NJ \& Chang JK 1999 Prolactin-releasing peptide-immunoreactivity in A1 and A2 noradrenergic neurons of the rat medulla. Brain Research 822 276-279.

Colthorpe KL, Nalliah J, Anderson ST \& Curlewis JD 2000 Adrenoceptor subtype involvement in suppression of prolactin secretion by noradrenaline. Journal of Neuroendocrinology 12 297-302.

Hinuma S, Habata Y, Fujii R, Kawamata Y, Hosoya M, Fukusumi S, Kitada C, Masuo Y, Asano T, Matsumoto H, Sekiguchi M, Kurokawa T, Nishimura O, Onda H \& Fujino M 1998 A prolactin-releasing peptide in the brain. Nature 393 272-276.

Hizume T, Watanobe H, Yoneda M, Suda T \& Schioth HB 2000 Involvement of prolactin-releasing peptide in the preovulatory luteinizing hormone and prolactin surges in the rat. Biochemical and Biophysical Research Communications 279 35-39.

Jarry H, Heuer H, Schomburg L \& Bauer K 2000 Prolactin-releasing peptides do not stimulate prolactin release in vivo. Neuroendocrinology 71 262-267.

Kawamata Y, Fujii R, Fukusumi S, Habata Y, Hosoya M, Hinuma S, Kitada C, Onda H, Nishimura O \& Fujino M 2000 Analyses for susceptibility of rat anterior pituitary cells to prolactin-releasing peptide. Endocrine 12 215-221.

Marchese A, Heiber M, Nguyen T, Heng HH, Saldivia VR, Cheng R, Murphy PM, Tsui LC, Shi X, Gregor P et al. 1995 Cloning and chromosomal mapping of three novel genes, GPR9, GPR 10, and GPR14, encoding receptors related to interleukin 8, neuropeptide $Y$, and somatostatin receptors. Genomics 29 335-344.

Maruyama M, Matsumoto H, Fujiwara K, Kitada C, Hinuma S, Onda H, Fujino M \& Inoue K 1999 Immunocytochemical localization of prolactin-releasing peptide in the rat brain. Endocrinology 140 2326-2333.

Matsumoto H, Noguchi J, Horikoshi Y, Kawamata Y, Kitada C, Hinuma S, Onda H, Nishimura O \& Fujino M 1999 Stimulation of prolactin release by prolactin-releasing peptide in rats. Biochemical and Biophysical Research Communications 259 321-324.

Minami S, Nakata T, Tokita R, Onodera H \& Imaki J 1999 Cellular localization of prolactin-releasing peptide messenger RNA in the rat brain. Neuroscience Letters 266 73-75.

Roland BL, Sutton SW, Wilson SJ, Luo L, Pyati J, Huvar R, Erlander MG \& Lovenberg TW 1999 Anatomical distribution of prolactin-releasing peptide and its receptor suggests additional functions in the central nervous system and periphery. Endocrinology $1405736-5745$.

Samson WK, Resch ZT, Murphy TC \& Chang JK 1998 Genderbiased activity of the novel prolactin releasing peptides: comparison with thyrotropin releasing hormone reveals only pharmacologic effects. Endocrine 9 289-291.

Sawangjaroen K \& Curlewis JD 1994 Effects of pituitary adenylate cyclase-activating polypeptide (PACAP) and vasoactive intestinal polypeptide (VIP) on prolactin, luteinizing hormone and growth hormone secretion in the ewe. Journal of Neuroendocrinology 6 549-555.

Sawangjaroen K, Sernia C \& Curlewis JD 1996 Effects of pituitary adenylate cyclase-activating polypeptide and vasoactive intestinal polypeptide on cyclic AMP accumulation in sheep pituitary cells in vitro. Journal of Endocrinology 148 545-552.

Sawangjaroen K, Anderson ST \& Curlewis JD 1997 Effects of pituitary adenylate cyclase-activating polypeptide (PACAP) and vasoactive intestinal polypeptide (VIP) on hormone secretion from sheep pituitary cells in vitro. Journal of Neuroendocrinology 9 279-286.

Seal LJ, Small CJ, Kim MS, Stanley SA, Taheri S, Ghatei MA \& Bloom SR 2000 Prolactin releasing peptide (PrRP) stimulates luteinizing hormone ( $\mathrm{LH}$ ) and follicle stimulating hormone (FSH) via a hypothalamic mechanism in male rats. Endocrinology 141 1909-1912.

Sokal RR \& Rohlf FJ 1995 Biometry: The Principles and Practice of Statistics in Biological Research, edn 3. San Francisco: WH Freeman and Company.

Tanguay RL \& Gallie DR 1996 Translational efficiency is regulated by the length of the $3^{\prime}$ untranslated region. Molecular and Cellular Biology 16 146-156.

Welch SK, O'Hara BF, Kilduff TS \& Heller HC 1995 Sequence and tissue distribution of a candidate G-coupled receptor cloned from rat hypothalamus. Biochemical and Biophysical Research Communications 209 606-613.

Yamada M, Ozawa A, Ishii S, Shibusawa N, Hashida T, Ishizuka T, Hosoya T, Monden T, Satoh T \& Mori M 2001 Isolation and characterization of the rat prolactin-releasing peptide gene: multiple TATA boxes in the promoter region. Biochemical and Biophysical Research Communications 281 53-56.

Received 6 December 2001

Accepted 7 March 2002 